\title{
Effect of different silicon sources on rattan-based silicon carbide ceramic prepared by one-step pyrolysis
}

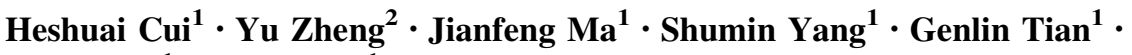 \\ Lili Shang ${ }^{1} \cdot$ Xing'e Liu ${ }^{1}$
}

Received: 13 May 2016/ Accepted: 26 October 2016/Published online: 10 December 2016

(C) The Japan Wood Research Society 2016

\begin{abstract}
Rattan-based silicon carbide (R-SiC) ceramics, $\mathrm{R}-\mathrm{SiC}_{\mathrm{SiO} 2}$ and $\mathrm{R}-\mathrm{SiC}_{\mathrm{Si}}$, were successfully prepared from silica $\left(\mathrm{SiO}_{2}\right)$ sol and silicon $(\mathrm{Si})$ powder, respectively. The rattan powder was impregnated, respectively, with $\mathrm{SiO}_{2}$ sol at ambient temperature and liquid melt-Si at high temperature. This was followed by one-step direct pyrolysis at $1500{ }^{\circ} \mathrm{C}$ under an argon (Ar) atmosphere. The final $\mathrm{SiC}$ samples were analyzed using mass analysis, X-ray diffraction (XRD), X-ray fluorescence (XRF), Fourier transform infrared spectroscopy (FT-IR), scanning electron microscope (SEM), energy dispersive $\mathrm{X}$-ray analysis (EDAX), and nitrogen $\left(\mathrm{N}_{2}\right)$ physisorption techniques. Experimental results showed that the mass residual of $\mathrm{R}_{-} \mathrm{SiC}_{\mathrm{Si}}$ (42.56 wt\%) was almost equal to $\mathrm{R}-\mathrm{SiC}_{\mathrm{SiO} 2}$ (42.45 wt\%). However, $\mathrm{R}-\mathrm{SiC}_{\mathrm{SiO} 2}$ had a higher yield of $\mathrm{SiC}$, a higher specific surface area and a more intact porous morphology preserved from the rattan biomass. In addition, some rod-like $\mathrm{SiC}$ whiskers and tablet-like $\mathrm{SiC}$ particles were found in $\mathrm{R}-\mathrm{SiC}_{\mathrm{SiO} 2}$. By comparison, $\mathrm{R}-\mathrm{SiC}_{\mathrm{Si}}$ had a large amount of unreacted $\mathrm{Si}$, as well as certain amount of $\mathrm{SiC}$ and unreacted $\mathrm{C}$. Thus, it can be concluded that $\mathrm{SiO}_{2}$ sols are more appropriate for use in preparation of $\mathrm{SiC}$ from rattan, whatever the porous microstructure, yield, and purity of SiC.
\end{abstract}

Xing'e Liu

liuxe@icbr.ac.cn

1 Key Lab of Bamboo and Rattan Science and Technology, International Centre for Bamboo and Rattan, No.8, Futong Dongdajie, Wangjing, Chaoyang District, Beijing 100102, China

2 Beijing Research Institute of Synthetic Crystals Co. Ltd., No.1, Hongsongyuan, Dongba, Chaoyang District, Beijing 100018, China
Keywords $\mathrm{SiC} \cdot \mathrm{Silica}$ sol $\cdot$ Silicon powder $\cdot$ Rattan $\cdot$ Onestep pyrolysis

\section{Introduction}

Silicon carbide $(\mathrm{SiC})$ ceramics have a wide variety of potential applications due to their excellent performances, such as extremely high hardness, high thermal resistance, high chemical stability, good mechanical properties, and good electronic properties [1-4]. Several studies have reported the preparation of $\mathrm{SiC}$ ceramic derived from naturally occurring plant biomass, such as wood, bamboo, and agricultural waste [5-10]. Naturally, occurring plants have complex hierarchical pore structure due to long-term genetic evolution and optimization [11]. The specific pore structure can provide the access passage, storage space, and reaction space for external silicon $(\mathrm{Si})$ sources. These structures can be preserved in the final $\mathrm{SiC}$ ceramic samples. In this way, plant-based $\mathrm{SiC}$ ceramics both possess unique biomorphic porous construction and traditional ceramic properties, having attracted much attention and led to extensive research.

In general, plant-based $\mathrm{SiC}$ ceramics can be prepared from different $\mathrm{Si}$ sources via two main routes, which are direct carbonization of $\mathrm{Si}$ [11-13] and carbothermal reduction of silica $\left(\mathrm{SiO}_{2}\right)[14,15]$. The direct carbonization of $\mathrm{Si}$ contains liquid Si infiltration (LSI) and vapor Si infiltration [16, 17] according to the state of Si. Liquid $\mathrm{Si}$ or vapor Si spontaneously infiltrates the pore structure of raw plants or their carbon templates. The $\mathrm{Si}$ source involved in carbothermal reduction of $\mathrm{SiO}_{2}$ mainly refers to $\mathrm{SiO}_{2}$ sol [18-20]. First, the raw biomass or carbon template is generally impregnated with $\mathrm{SiO}_{2}$ sol once or several times. They are then placed in a hightemperature condition to allow for the formation of SiC. Many 
previous studies have reported that the two main existing routes can produce $\mathrm{SiC}$ ceramics from plant biomasses that have multiple and special properties, such as low density, high surface area to volume, high permeability, and high specific strength [21, 22]. However, the differences between $\mathrm{SiC}$ ceramics derived from two main routes have not been recognized clearly. To compensate for this problem, researchers are expected to carry out a study to compare these two different $\mathrm{SiC}$ ceramics and to find and determine the effects of different preparation routes or different $\mathrm{Si}$ sources on the $\mathrm{SiC}$ ceramics.

Rattan is a highly important non-timber forest resource next to wood and bamboo without branches and seasonal rings, which exhibits good processability owing to its low density, light weight, and high toughness [23, 24]. Rattan possesses hierarchical pore distribution and interconnecting pore structure $(\sim 300,6-20$, and $1-3 \mu \mathrm{m})$, and the total porosity (55-68\%) of rattan is higher than those of wood or bamboo [25]. In this context, it is expected that rattan with pore structure would be easier for the infiltration of $\mathrm{Si}$ source, e.g., Si powder and $\mathrm{SiO}_{2}$ sol, and increase the intimate contact area between the carbon source (rattan structure) and $\mathrm{Si}$ source, making it is possible to promote the formation of $\mathrm{SiC}$ at relatively low temperature, high yield, purity, and porosity $[8,10]$. Moreover, rattan-based SiC (R$\mathrm{SiC}$ ) ceramics are not only synthesized via an environmental-friendly method, but also provide another utilization option for rattan resources. In the past, the processing and utilization of rattan and the preparation of plant-based $\mathrm{SiC}$ ceramics have been intensively studied, but investigations into R-SiC ceramics have been limited [26-29]. Furthermore, the systematical investigation on the effect of different $\mathrm{Si}$ sources ( $\mathrm{Si}$ powder and $\mathrm{SiO}_{2}$ sol) on $\mathrm{SiC}$ ceramics prepared from naturally occurring plant biomass has rarely been addressed. This paper reports on the results of processing of $\mathrm{R}-\mathrm{SiC}$ ceramic derived from $\mathrm{Si}$ powder and $\mathrm{SiO}_{2}$ sol via one-step pyrolysis. In addition, the one-step pyrolysis achieves that $\mathrm{SiC}$ can be obtained directly from the natural rattan infiltrated by $\mathrm{Si}$ source without the carbonization of natural rattan to form rattan charcoal before the infiltration of $\mathrm{Si}$ source. The paper analyzes the differences between these two $\mathrm{SiC}$ samples using relevant phase, element, microstructure, and pore characterization techniques. The effect of the Si source on prepared $\mathrm{R}-\mathrm{SiC}$ ceramics and the superior Si source is determined.

\section{Materials and methods}

\section{Preparation of starting materials}

Rattan. Daemonorops Margaritae (Hance) Beccari is the only species in China, which was acquired from Hainan province and used in this study. Air-dried rattans selected randomly were first sawed into $3-5 \mathrm{~cm}$ cylinder samples perpendicular to the axial direction, and then chopped into strips parallel to the axial direction. Finally, the samples were milled into powder of about $150 \mu \mathrm{m}$. The obtained rattan powders were left untreated and stored as a carbon source for the synthesis of the $\mathrm{SiC}$ ceramic.

$\mathrm{Si}$ powder provided by Beijing Sinoma Synthetic Crystals Co., Ltd. was well mixed with the rattan powder using a planetary ball mill (Retsch PM-100, Germany) at room temperature at a mass ratio of $7: 20$ to produce rattan/silicon material. The mass ratio was calculated according to the highest carbon yield (15\%) of rattan above $1000{ }^{\circ} \mathrm{C}$ in preliminary work and the stoichiometric ratio of $1: 1(\mathrm{Si}: \mathrm{C})$ from the reaction: $\mathrm{Si}+\mathrm{C} \rightarrow \mathrm{SiC}$. $\mathrm{SiO}_{2}$ sol $(20 \%$ solid content by weight in this study) was prepared from the mixture of tetraethoxysilane $\left[\mathrm{Si}\left(\mathrm{OC}_{2}\right.\right.$ $\left.\mathrm{H}_{5}\right)_{4}$, TEOS $]$, ethyl alcohol $\left[\mathrm{C}_{2} \mathrm{H}_{5} \mathrm{OH}, \mathrm{EtOH}\right]$, and distilled water $\left[\mathrm{H}_{2} \mathrm{O}\right]$ at a molar ratio of $1: 4: 4$ with the addition of small amount of hydrochloric acid to obtain $\mathrm{pH}=2.5$. This is the optimal $\mathrm{pH}$ for increasing the gelation rate by a sol-gel process as described in the previous studies [30-32]. The infiltration of silica sol into rattan powder was accomplished via a vacuum-pressure method. Rattan powder and sufficient silica sol were first blended in a glass beaker, which was then placed into a self-made high-pressure reactor kettle and evacuated for $20 \mathrm{~min}$ before being held for $1 \mathrm{~h}$. The kettle was then filled with nitrogen $\left(\mathrm{N}_{2}\right)$ to raise the pressure to $0.8 \mathrm{MPa}$ and held for $2 \mathrm{~h}$. To remove other solvents and promote full condensation and gelation reaction of the $\mathrm{SiO}_{2}$ sol contained in rattan powder, the infiltrated rattan powder was placed in a constant temperature and humidity chamber at $60{ }^{\circ} \mathrm{C}$ and $70 \%$ humidity. The infiltrated rattan powder was held in this condition for 2 days, and then dried for $2 \mathrm{~h}$ at $60^{\circ} \mathrm{C}$, and, finally, oven dried at $105^{\circ} \mathrm{C}$. Thus, the rattan/silica material was prepared, and the mass ratio of $\mathrm{SiO}_{2}$ gel/rattan powder (8:11) in this material was calculated through the $15 \%$ carbon yield of rattan and the following formula: $n=\left(m_{1}-m_{0}\right) / m_{0}$, where $m_{0}$ was the mass of rattan powder before the solgel process and $m_{1}$ was the mass of rattan powder after the sol-gel process. The untamped bulk density of rattan/ silicon $\left(324 \mathrm{~kg} / \mathrm{m}^{3}\right)$ and rattan/silica $\left(410 \mathrm{~kg} / \mathrm{m}^{3}\right)$ materials was determined according to the European standard (EN 725-9-2006) [33].

\section{Preparation of $\mathrm{SiC}$ ceramic}

One-step pyrolysis method was used to prepare $\mathrm{SiC}$ ceramics, including carbothermal reduction and direct carbonization. The schematic diagram of the experimental procedure used for the preparation of the $\mathrm{R}-\mathrm{SiC}$ ceramic 


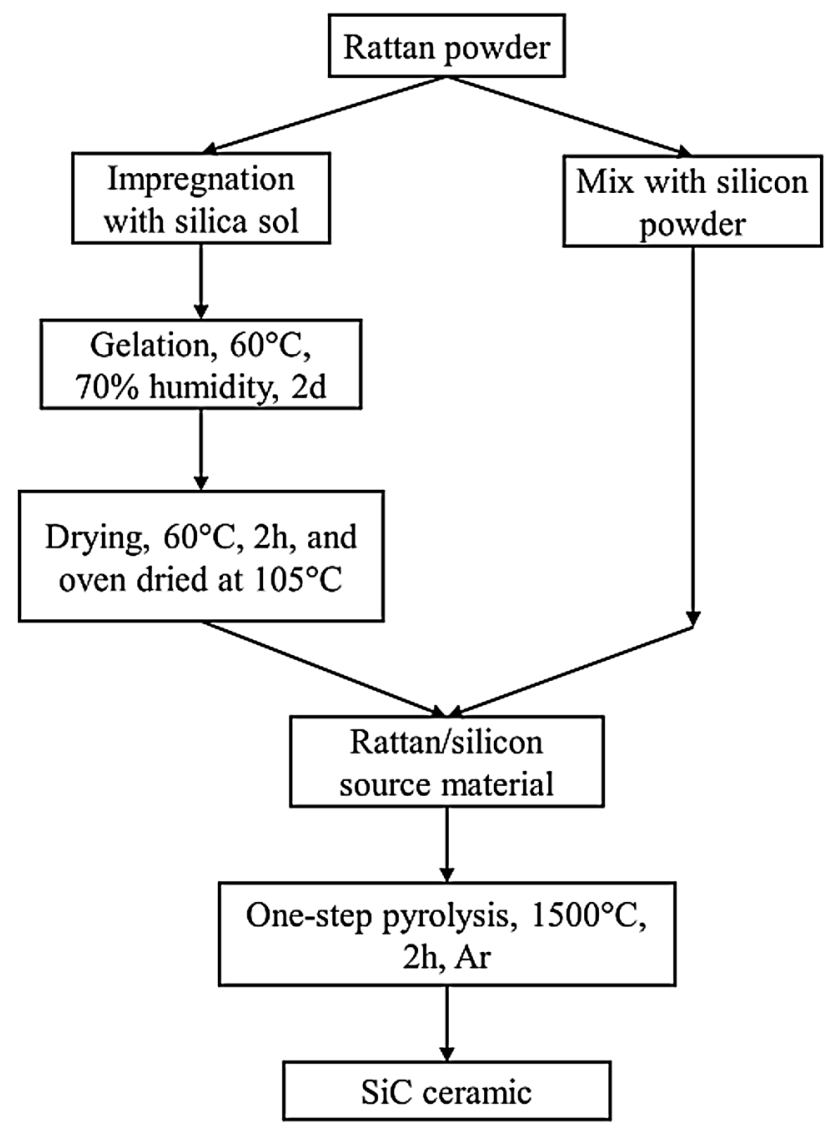

Fig. 1 Schematic diagram of rattan-based $\mathrm{SiC}(\mathrm{R}-\mathrm{SiC})$ ceramics preparation process

sample is shown in Fig. 1. Carbothermal reduction and direct carbonization of two pre-prepared samples, i.e., rattan/silicon (54.7 g) and rattan/silica (50.5 g) material, were, respectively, carried out in a tube furnace at $1500{ }^{\circ} \mathrm{C}$ under an argon (Ar) atmosphere to form $\mathrm{SiC}$ ceramic. Two samples held by an alumina crucible were placed in the tube furnace and heated. To avoid the formation of microcracks in the reactants resulting from the fast heating rate, a multi-step heat treatment process was used. At first, the temperature of the furnace was raised up to $600{ }^{\circ} \mathrm{C}$ at a heating rate of $5{ }^{\circ} \mathrm{C} / \mathrm{min}$ and held for $1 \mathrm{~h}$ to allow complete carbonization of the rattan powder. Next, the temperatures were, respectively, raised to $1100{ }^{\circ} \mathrm{C}$ at a rate of $5{ }^{\circ} \mathrm{C} / \mathrm{min}$ and $1300{ }^{\circ} \mathrm{C}$ at a rate $4{ }^{\circ} \mathrm{C} / \mathrm{min}$. Finally, the reactants were heated at a rate of $2^{\circ} \mathrm{C} / \mathrm{min}$ to the desired temperature $\left(1500{ }^{\circ} \mathrm{C}\right)$ and held for $2 \mathrm{~h}$ at this temperature to promote full reaction between the $\mathrm{C}$ source and the $\mathrm{Si}$ source. Subsequently, the furnace was cooled down to room temperature at a programmed cooling rate. The prepared two $\mathrm{R}-\mathrm{SiC}$ ceramic samples derived from the rattan/silicon material and rattan/silica material were, respectively, recorded as $\mathrm{R}-\mathrm{SiC}_{\mathrm{Si}}$ and $\mathrm{R}-\mathrm{SiC} \mathrm{SiO}_{\mathrm{S}}$, where the subscripts represent the Si source.

\section{Characterization}

Mass changes in the samples during the transformation of rattan/silica source material into $\mathrm{SiC}$ ceramic were measured using an analytical balance (sensitivity $0.0001 \mathrm{~g}$, Mettler-Toledo PL303-IC, Switzerland). These values were then used in mass residue calculations. The phase composition and crystallographic structure of SiC samples were determined via X-ray diffraction (XRD, Bruker AV300, Holland), using a nickel filtered $\mathrm{Cu} \mathrm{K}_{\alpha}$ radiation over the $2 \theta$ range of $5-90^{\circ}$ at a scanning speed of $4 \% \mathrm{~min}$. Meanwhile, the elemental analysis of $\mathrm{SiC}$ samples was conducted on the X-ray fluorescence (XRF, Shimadzu1800, Japan). The chemical bonds and functional groups of the $\mathrm{SiC}$ samples were investigated using a Fourier transform infrared spectroscopy (FT-IR, Nexus670, America) at ambient conditions. The morphology and microstructure of SiC samples were examined under an environmental scanning electron microscope (FESEM, FEI XL-30, America). Meanwhile, an energy dispersive X-ray analysis (EDAX, FEG132-10, America) equipped with FESEM was carried out to determinate the element composition of the $\mathrm{SiC}$ samples corresponding to the SEM images. The specific surface area (SSA) of SiC samples was obtained by $\mathrm{N}_{2}$ physisorption instrument (ASAP2020, America).

\section{Results and discussion}

\section{Mass change}

The sample masses before and after the one-step pyrolysis were measured. Mass residue was calculated from these mass measurements. This experiment was repeated three times using identical processes and conditions to reduce random error. Figure 2 shows the mass residue of $\mathrm{R}-\mathrm{SiC}_{\mathrm{Si}}$ and $\mathrm{R}-\mathrm{SiC}_{\mathrm{SiO} 2}$ after one-step pyrolysis. The average mass residue of the two $\mathrm{SiC}$ samples is almost the same (42.56 $\mathrm{wt} \%$ of $\mathrm{R}-\mathrm{SiC}_{\mathrm{Si}}$ and $42.45 \mathrm{wt} \%$ of $\mathrm{R}-\mathrm{SiC}_{\mathrm{SiO} 2}$ ), indicating the near-equal mass loss ratio. During the formation of the carbon template, the plant biomass exhibited evident mass loss due to the carbonization, as described in [7, 14, 34]. The rattan content of the rattan/silicon material and rattan/ silica material are 74.00 and $57.18 \mathrm{wt} \%$, respectively. In the identical pyrolysis condition, the rattan/silicon material has higher carbonization loss than rattan/silica material during the carbonization of the rattan powder. As a consequence, the carbothermal reduction of $\mathrm{SiO}_{2}$ occurs in the preparation of $\mathrm{R}-\mathrm{SiC}_{\mathrm{SiO} 2}$ to compensate for the whole mass loss of rattan/silica material and results in the near-equal mass loss ratio of $\mathrm{R}-\mathrm{SiC}_{\mathrm{Si}}$ to $\mathrm{R}-\mathrm{SiC}_{\mathrm{SiO} 2}$, suggesting the formation of $\mathrm{SiC}$ in $\mathrm{R}-\mathrm{SiC}_{\mathrm{SiO} 2}$. 


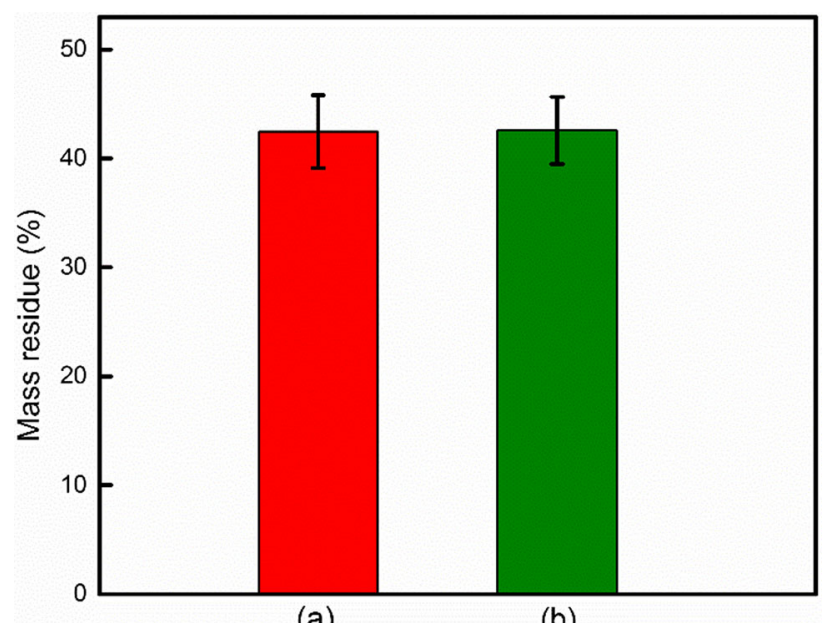

(a)

(b)

Fig. 2 Mass residue of a $\mathrm{R}-\mathrm{SiC}_{\mathrm{SiO} 2}$ and $\mathbf{b} \mathrm{R}-\mathrm{SiC}_{\mathrm{Si}}$. $\mathrm{R}-\mathrm{SiC}$ represents the rattan-base $\mathrm{SiC}$, and the subscripts represent the $\mathrm{Si}$ source

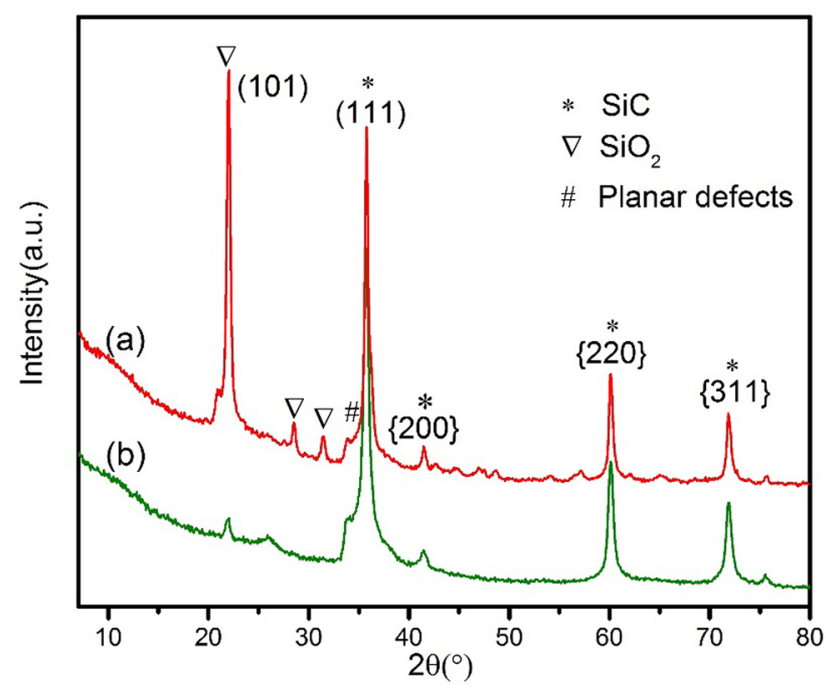

Fig. 3 X-ray diffraction (XRD) pattern of a $\mathrm{R}-\mathrm{SiC}_{\mathrm{SiO} 2}$ and $\mathbf{b} \mathrm{R}-\mathrm{SiC}_{\mathrm{Si}}$. $\mathrm{R}$-SiC represents the rattan-base $\mathrm{SiC}$, and the subscripts represent the Si source

\section{XRD analysis}

XRD technique was used to investigate the phase evolution during the formation process of $\mathrm{SiC}$. Figure 3 shows the XRD patterns of $\mathrm{R}-\mathrm{SiC}_{\mathrm{SiO} 2}$ and $\mathrm{R}-\mathrm{SiC}_{\mathrm{Si}}$ after one-step pyrolysis. It can be seen from the two patterns (Fig. 3) that several sharp peaks attributed to $\mathrm{SiC}$ are positioned around $2 \theta=35.8^{\circ}, 41.5^{\circ}, 60.1^{\circ}$, and $71.9^{\circ}$. These peaks are associated with diffraction from the (111), (200), (220), and (311) planes of $\beta$-SiC (JCPDS Card No. 29-1129), respectively. In addition, an unconspicuous peak (at $2 \theta=33.9^{\circ}$ ) near by the (111) plane of $\mathrm{SiC}$ is observed, which is characteristic of the planar defects (stacking faults and rotational twins) of (111) plane in the $\beta$-SiC structure $[35,36]$. From Fig. 3 , it is obvious that the two patterns have no broad peak in the whole range of $10-80^{\circ}$, which indicates the absence of an amorphous phase in $\mathrm{R}-\mathrm{SiC}_{\mathrm{Si}}$ and $\mathrm{R}-\mathrm{SiC}_{\mathrm{SiO} 2}$. Apart from the peaks of $\beta$-SiC, well-defined crystalline sharp peaks of cristobalite (JCPDS Card No. 39-1425) can also be found in the pattern of the $\mathrm{SiC}$ samples, which suggests the existence of crystalline $\mathrm{SiO}_{2}$ in $\mathrm{R}-\mathrm{SiC}_{\mathrm{Si}}$ and $\mathrm{R}-\mathrm{SiC}_{\mathrm{SiO} 2}$. From the above results, it can be assumed that reaction temperature $\left(1500{ }^{\circ} \mathrm{C}\right)$ was sufficiently high for the formation of crystalline $\mathrm{SiC}$ structures, but $\mathrm{SiO}_{2}$ was not completely consumed.

The two XRD patterns show obvious differences between $\mathrm{R}-\mathrm{SiC}_{\mathrm{SiO} 2}$ and $\mathrm{R}-\mathrm{SiC} \mathrm{Si}_{\text {at }}$ the range of $20-33^{\circ}$ (Fig. 3). The pattern (a) of $\mathrm{R}_{-} \mathrm{SiC}_{\mathrm{SiO} 2}$ has three peaks of cristobalite (crystalline $\mathrm{SiO}_{2}$ ) located at $2 \theta=22.0^{\circ}, 28.5^{\circ}$, and $31.5^{\circ}$ corresponding to the (101), (111), and (102) planes, while the pattern (b) of $\mathrm{R}-\mathrm{SiC}_{\mathrm{Si}}$ only has a small weak peak of cristobalite positioned around $2 \theta=22.0^{\circ}$ corresponding to the (101) plane. The difference of cristobalite in Fig. 3 indicates a small amount of $\mathrm{SiO}_{2}$ in $\mathrm{R}-\mathrm{SiC}_{\mathrm{Si}}$. The existence of cristobalite in $\mathrm{R}-\mathrm{SiC}_{\mathrm{Si}}$ can be attributed to $\mathrm{SiO}_{2}$ reserved from the rattan after one-step pyrolysis $[8,27]$. The high-intensity peak $\left(2 \theta=22.0^{\circ}\right)$ and two small peaks of cristobalite in pattern (a) suggest that R- $-\mathrm{SiC}_{\mathrm{SiO} 2}$ contains $\mathrm{SiO}_{2}$ in large quantities. $\mathrm{SiO}_{2}$ existing in $\mathrm{R}-\mathrm{SiC}_{\mathrm{SiO} 2}$ originated mainly from the $\mathrm{SiO}_{2}$ sol besides the rattan. Some of them were not completely consumed by the carbothermal reduction reaction between $\mathrm{C}$ and $\mathrm{SiO}_{2}$. Furthermore, $\mathrm{SiO}_{2}$ sol is found to have a higher intake of $\mathrm{SiO}_{2}$ in the rattan powder than in previously reported for studies of bulk rattan $[11,36]$. The higher intake of silica indicates that $\mathrm{R}-\mathrm{SiC}$ may be prepared at a higher yield. In additionally, XRF technique was used to determine relative content of the concerned elements of $\mathrm{R}-\mathrm{SiC}_{\mathrm{SiO} 2}$ and $\mathrm{R}-\mathrm{SiC}_{\mathrm{Si}}$. Table 1 shows the effect of different $\mathrm{Si}$ source on the relative content of $\mathrm{SiC}$, residual $\mathrm{C}$, and $\mathrm{SiO}_{2}$ or $\mathrm{Si}$, which supports the XRD analysis.

\section{FT-IR analysis}

The chemical bonds and functional groups of the prepared $\mathrm{SiC}$ samples were displayed on the FT-IR spectra, as shown in Fig. 4. It can be observed that the spectra of $\mathrm{R}-\mathrm{SiC}_{\mathrm{SiO} 2}$ and $\mathrm{R}-\mathrm{SiC}_{\mathrm{Si}}$ are extremely similar, implying the

Table 1 Relative content of phase composition in $\mathrm{R}_{-}-\mathrm{SiC}_{\mathrm{SiO} 2}$ and $\mathrm{R}-\mathrm{SiC}_{\mathrm{Si}}$

\begin{tabular}{|c|c|c|c|c|}
\hline \multirow[t]{2}{*}{ Sample } & \multicolumn{4}{|c|}{ Weight percentage $\%$} \\
\hline & $\mathrm{SiC}$ & $\mathrm{C}$ & $\mathrm{SiO}_{2}$ & $\mathrm{Si}$ \\
\hline $\mathrm{R}-\mathrm{SiC}_{\mathrm{SiO} 2}$ & 24.57 & 55.79 & 19.64 & - \\
\hline $\mathrm{R}-\mathrm{SiC}_{\mathrm{Si}}$ & 23.28 & 41.02 & 4.82 & 29.3 \\
\hline
\end{tabular}

$R-S i C$ rattan-base $\mathrm{SiC}$ 


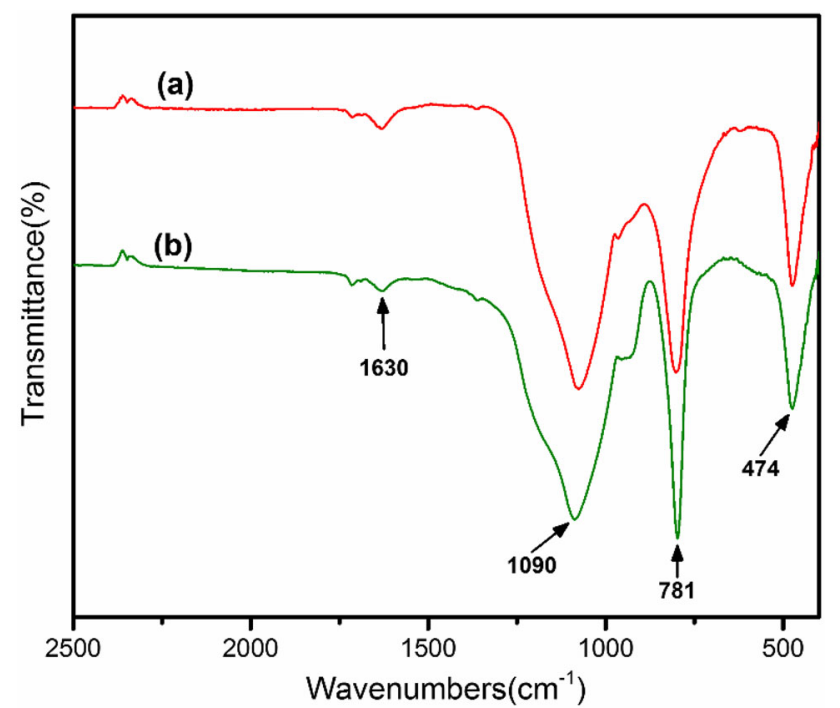

Fig. 4 Fourier transform infrared spectroscopy (FT-IR) spectra of a $\mathrm{R}-\mathrm{SiC}_{\mathrm{SiO} 2}$ and $\mathbf{b} \mathrm{R}-\mathrm{SiC}_{\mathrm{Si}}$. $\mathrm{R}-\mathrm{SiC}$ represents the rattan-base $\mathrm{SiC}$, and the subscripts represent the $\mathrm{Si}$ source

similar chemical bonds in the two $\mathrm{SiC}$ samples. It can be found from Fig. 4 that the peak ascribed to anti-symmetric $\mathrm{Si}-\mathrm{C}$ stretching vibration is located at $781 \mathrm{~cm}^{-1}$. This indicates that $\mathrm{SiC}$ has been formed [37, 38]. In addition, the extremely weak peak at $1630 \mathrm{~cm}^{-1}$, characteristic of the vibration of $\mathrm{C}-\mathrm{C}$ stretching, was observed as well. The weak peak indicates the trace residue of carbon derived from rattan, while the disappearance of amorphous structures in XRD patterns indicates the existence of carbon in less and lower graphitization after a higher high-temperature pyrolysis [39]. The two strong peaks at 1090 and $474 \mathrm{~cm}^{-1}$, which are assigned to $\mathrm{Si}-\mathrm{O}-\mathrm{Si}$ stretching and anti-stretching vibrations, were also found in spectra (a) and (b), as shown in Fig. 4, suggesting the existence of $\mathrm{SiO}_{2}$ in $\mathrm{R}-\mathrm{SiC}_{\mathrm{Si}}$ and $\mathrm{R}-\mathrm{SiC}_{\mathrm{SiO} 2}$. On peak shape and transmittance, the relative transmittance ratios of $\mathrm{SiO}_{2} / \mathrm{SiC}$ peak of the two $\mathrm{SiC}$ samples are almost equal (1.7 of $\mathrm{R}-\mathrm{SiC}_{\mathrm{Si}}$ and 1.5 of $\mathrm{R}-\mathrm{SiC}_{\mathrm{SiO} 2}$ ). In combination with the content of $\mathrm{SiO}_{2}$ in $\mathrm{SiC}$ samples from the XRD analysis results, it can simultaneously demonstrate that $\mathrm{R}-\mathrm{SiC}_{\mathrm{Si}}$ contains $\mathrm{SiC}$ in less quantity, while $\mathrm{R}-\mathrm{SiC}_{\mathrm{SiO} 2}$ contains $\mathrm{SiC}$ in larger quantity. In other words, $\mathrm{SiO}_{2}$ sol has a higher yield of $\mathrm{SiC}$ than $\mathrm{Si}$ powder for the preparation of $\mathrm{R}-\mathrm{SiC}$ ceramics.

\section{SEM and EDAX analysis}

As shown in Fig. 5, the morphology and element composition of $\mathrm{R}_{-} \mathrm{SiC}_{\mathrm{Si}}$ can be obtained via SEM and EDAX technique. Figure $5 \mathrm{a}$ shows the common appearance in $\mathrm{R}-\mathrm{SiC}_{\mathrm{Si}}$, displaying two entirely different morphology structures: strips and particles. The corresponding highmagnification SEM images of the strips and particles are, respectively, shown in Fig. 5b and c. It can be observed from Fig. 5b that the morphology consists of micron-sized bulk particles and small particles. The small particles not only attach on the surface of bulk particles, but also stack on each other to form large particles of different sizes. The major element composition of the particles is $\mathrm{Si}, \mathrm{C}, \mathrm{P}$, and $\mathrm{O}$, as shown in Fig. $5 \mathrm{~d}$, indicating that the particles
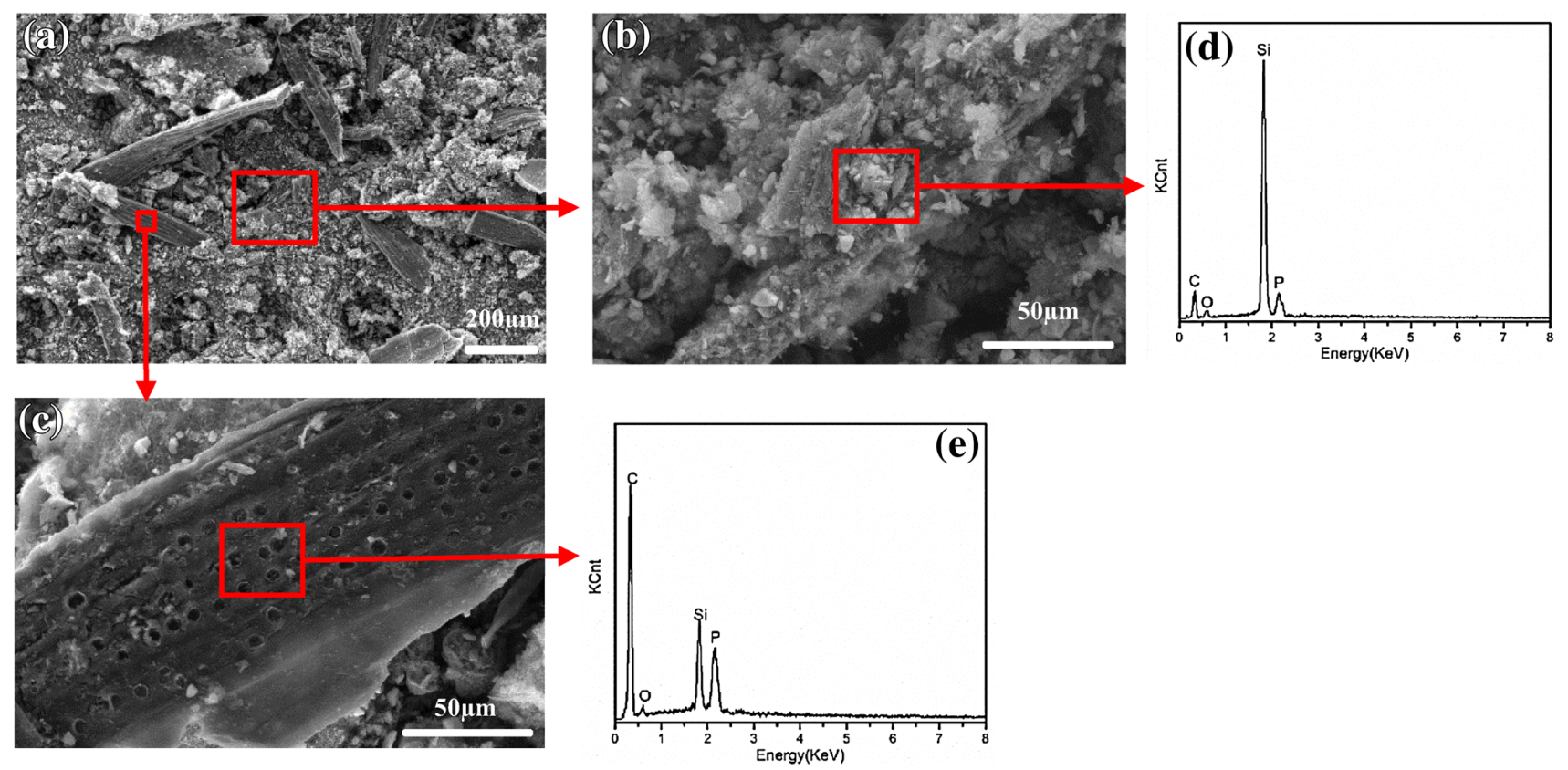

Fig. 5 Scanning electron microscope (SEM) image of $\mathrm{R}_{-} \mathrm{SiC}_{\mathrm{Si}}$ (a) and the corresponding high-magnification SEM image (b, c) and energy dispersive X-ray analysis (EDAX) spectrum $(\mathbf{d}, \mathbf{e})$. $\mathrm{R}$-SiC represents the rattan-base $\mathrm{SiC}$, and the subscripts represent the $\mathrm{Si}$ source 

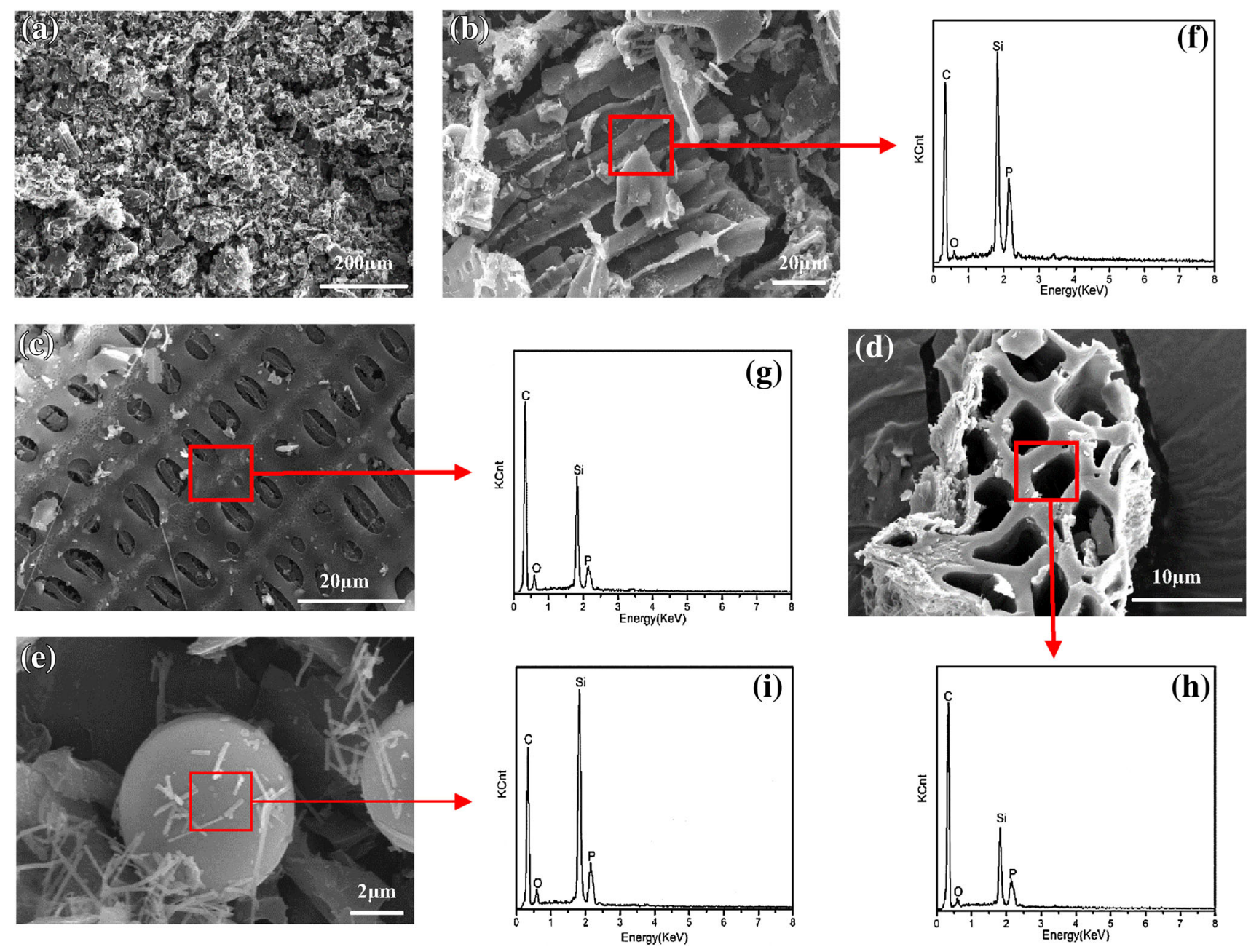

Fig. 6 Scanning electron microscope (SEM) image of $\mathrm{R}-\mathrm{SiC}_{\mathrm{SiO} 2}$ (a) and the corresponding high-magnification SEM image (b-e) and energy dispersive X-ray analysis (EDAX) spectrum $(\mathbf{f}-\mathbf{i})$. R-SiC represents the rattan-base $\mathrm{SiC}$, and the subscripts represent the $\mathrm{Si}$ source

composed of $\mathrm{SiC}$ and $\mathrm{Si}$ incorporation with the much weaker signal intensity of $\mathrm{C}$ than $\mathrm{Si}(\mathrm{Si} / \mathrm{C}$ intensity ratio $\approx 9.4$ ). It can be concluded that the particles of $\mathrm{R}-\mathrm{SiC}_{\mathrm{Si}}$ contain a small quantity of $\mathrm{SiC}$ and abundant residual $\mathrm{Si}$. Figure $5 \mathrm{c}$ exhibits a corresponding high-magnification microstructure of the strips morphology, where many round holes with diameters of several micrometers are arranged in columns on the surface. The round holes on the surface of the strips are similar to anatomical structure of rattan and are likely to have originated from the pits on the plant's cell wall or perforations of the vessels [17]. The EDAX spectrum (Fig. 5e) reveals that the major element composition of strips is $\mathrm{C}, \mathrm{Si}, \mathrm{P}$, and $\mathrm{O}$. The element type of strips is the same as the particles, but the signal intensity of $\mathrm{C}$ is much stronger than $\mathrm{Si}(\mathrm{Si} / \mathrm{C}$ intensity ratio $\approx 0.4$ ), indicating that the main composition of strips is $\mathrm{SiC}$ and $\mathrm{C}$. The existence of $\mathrm{C}$ makes it clear that the liquid melt-Si did not completely infiltrated the rattan powder during the pyrolysis process, resulting in the incomplete silicification of the rattan charcoal and the preservation of the porous morphology [36]. In summary, $\mathrm{R}-\mathrm{SiC}_{\mathrm{Si}}$ mainly consists of $\mathrm{SiC}$, unreacted $\mathrm{C}$, and excess $\mathrm{Si}$, which is similar to those of previous studies [10, 25, 27, 34, 40].

SEM images and EDAX spectrums of $\mathrm{R}_{-} \mathrm{SiC}_{\mathrm{SiO} 2}$ after one-step pyrolysis are shown in Fig. 6. Compared to the SEM images of $\mathrm{R}^{-\mathrm{SiC}_{\mathrm{Si}}}$ (Fig. 5), it is worthy of note that several significant changes were observed in the general morphology of $\mathrm{R}-\mathrm{SiC}_{\mathrm{SiO} 2}$. Figure 6a only shows a single fragmentary morphology of $\mathrm{R}-\mathrm{SiC}_{\mathrm{SiO} 2}$ from a low-magnification SEM image, which is obviously different from Fig. 5a. In general, several morphologies can be found in $\mathrm{R}-\mathrm{SiC}_{\mathrm{SiO} 2}$ from the corresponding high-magnification SEM images (Fig. 6b-e). One of the morphologies is broken tubular structures in the axial direction of rattan stem. The structures are $\mathrm{SiC}$ according to the EDAX spectrum ( $\mathrm{Si} / \mathrm{C}$ intensity ratio $\approx 1.2$ ), as shown in Fig. 6 f, indicating that the tubular structures of rattan were damaged during the formation of SiC. Some flake structures can also be seen in 
Fig. 6c, displaying several columns of oval holes on their surface. The flake structures are similar to Fig. $5 \mathrm{c}$ of $\mathrm{R}-\mathrm{SiC}_{\mathrm{Si}}$ and it can be assumed that the precursor of the flake structures is perforated plates contained specifically in the vessel. The corresponding EDAX spectrum of the flake structures (Fig. $6 \mathrm{~g}$ ), in which the $\mathrm{Si} / \mathrm{C}$ intensity ratio is about 0.6 , indicates that the flake structures are composed of $\mathrm{SiC}$ and unreacted C. Comparing Fig. 6c, g of R-SiC $\mathrm{SiO}_{2}$ with Fig. 5 c, e of $\mathrm{R}-\mathrm{SiC}_{\mathrm{Si}}, \mathrm{R}-\mathrm{SiC}_{\mathrm{SiO} 2}$ in Fig. $6 \mathrm{c}$ preserved the pore structure of rattan better than Fig. $5 \mathrm{c}$, and the corresponding $\mathrm{Si} / \mathrm{C}$ intensity ratio of Fig. $6 \mathrm{~g}$ is larger than in Fig. 5e, which reveals that the amount of residual $\mathrm{SiO}_{2}$ in pore structure of $\mathrm{R}-\mathrm{SiC}_{\mathrm{SiO} 2}$ is larger than residual $\mathrm{Si}$ in $\mathrm{R}_{-} \mathrm{SiC}_{\mathrm{Si}}$. In addition, Fig. 6d displays a complete porous structure, which is extremely similar to the natural microstructure of rattan. It can be found from Fig. $6 \mathrm{~h}$ that the pore structure contains $\mathrm{C}, \mathrm{Si}, \mathrm{P}$, and $\mathrm{O}$ elements and has a lower $\mathrm{Si} / \mathrm{C}$ intensity ratio (0.4), suggesting the generation of $\mathrm{SiC}$ and the existence of more unreacted C. As a result of the above three morphologies, it can be concluded that rattan powder is impregnated by $\mathrm{SiO}_{2}$ sol better than high-temperature liquid melt-Si.

It was reported that the most obvious and significant aim of $\mathrm{SiC}$ ceramics prepared from the natural plant biomass was to mimic the biological cellular morphology in a ceramic microstructure [9, 41, 42]. From the above analysis of the $\mathrm{SEM}$ and EDAX results, it can be concluded that $\mathrm{R}-\mathrm{SiC}_{\mathrm{SiO} 2}$ can retain the natural and graceful pore structure of rattan, but most of $\mathrm{R}-\mathrm{SiC}_{\mathrm{Si}}$ was embedded by unreacted $\mathrm{Si}$, resulting in the rare appearance of pore structures derived from rattan powder. This finding is explained by the fact that the $\mathrm{SiO}_{2}$ sol was able to infiltrate deeper into the rattan powder and had closer contact with cell wall of rattan at ambient temperature, while the liquid melt-Si failed to completely infiltrate into the rattan powder, which leaded to the incomplete reaction between $\mathrm{Si}$ and $\mathrm{C}$. In this way, little $\mathrm{SiC}$ was synthesized and lots of unreacted $\mathrm{Si}$ and $\mathrm{C}$ were left over in $\mathrm{R}-\mathrm{SiC} \mathrm{Si}_{\mathrm{Si}}$, where $\mathrm{Si}$ was left on the surface of $\mathrm{R}-\mathrm{SiC} \mathrm{Si}_{\mathrm{Si}}$, and $\mathrm{C}$ was left inside $\mathrm{R}-\mathrm{SiC}_{\mathrm{Si}}$, resulting in the coverage of the pore structure. Moreover, the unreacted $\mathrm{C}$ had a great influence on the porous structures of $\mathrm{R}_{-} \mathrm{SiC}_{\mathrm{SiO}}$, with the porous structures becoming more and more complete with the increase of unreacted $C[36,43]$. Due to the high thermal resistance of $\mathrm{SiC}$, these porous $\mathrm{R}-\mathrm{SiC}_{\mathrm{SiO} 2}$ can be applied in hot gas filters in industrial and automobile exhausts, catalyst supports, and porous burners at high temperature [4, 22]. Figure 6e shows a high-magnification SEM image inside the broken tubular structures, indicating two particular morphology structures with the size of several micrometers, i.e., tablet-like e and rod-like structures. The EDAX spectrum (Fig. 6i) of these two particular morphology suggests that they are $\mathrm{SiC}$ according to the $\mathrm{Si} / \mathrm{C}$ intensity ratio $\approx 1.4$, which are, respectively, called $\mathrm{SiC}$ particles or whiskers in other studies [8]. The particle and whisker may be resulted from the reaction of $\mathrm{SiO}$ vapor and $\mathrm{CO}$, which are derived from $\mathrm{C}_{(\mathrm{s})}+\mathrm{SiO}_{2(\mathrm{~s})} \rightarrow \mathrm{CO}_{(\mathrm{g})}+\mathrm{SiO}_{(\mathrm{g})}$.

In addition, the $\mathrm{P}$ and $\mathrm{O}$ elements also can be observed from EDAX spectrums of the final $\mathrm{R}-\mathrm{SiC}_{\mathrm{SiO} 2}$ and $\mathrm{R}-\mathrm{SiC} \mathrm{Si}_{\mathrm{S}}$, as shown in Figs. 5 and 6. It can be assumed that $\mathrm{P}$ element is derived from rattan powder and plays a catalytic role in the formation of $\mathrm{SiC}$, which is consistent with other studies [36]. The $\mathrm{O}$ element only comes from $\mathrm{SiO}_{2}$ after pyrolysis, suggesting the existence of $\mathrm{SiO}_{2}$ in $\mathrm{R}-\mathrm{SiC}_{\mathrm{SiO} 2}$ and $\mathrm{R}-\mathrm{SiC}_{\mathrm{Si}}$. The results agree well with the XRD and FT-IR analysis.

\section{Specific surface area analysis}

The specific surface area of $\mathrm{R}-\mathrm{SiC}_{\mathrm{SiO}}, \mathrm{R}-\mathrm{SiC}_{\mathrm{Si}}$, and rattan powder is shown in Table 2. It shows that the formation of $\mathrm{SiC}$ can result in a decrease in specific surface area of rattan powder, and the same results occur in other papers $[11,14,27]$. During the transformation from rattan to $\mathrm{R}-\mathrm{SiC}_{\mathrm{SiO} 2}$ and $\mathrm{R}-\mathrm{SiC}_{\mathrm{Si}}$, the specific surface area decreases from 22.15 to 21.99 and $6.25 \mathrm{~m}^{2} / \mathrm{g}$, respectively. Furthermore, $\mathrm{R}-\mathrm{SiC}_{\mathrm{SiO} 2}$ possesses a much higher specific surface area than $\mathrm{R}-\mathrm{SiC}_{\mathrm{Si}}$, mainly due to the coverage of residual $\mathrm{Si}$ in $\mathrm{R}-\mathrm{SiC}_{\mathrm{Si}}$. The results agree well with the above SEM and EDAX analysis.

On the basis of the above results and discussions, a schematic diagram for the formation mechanism of $\mathrm{R}-\mathrm{SiC}_{\mathrm{SiO} 2}$ and $\mathrm{R}-\mathrm{SiC}_{\mathrm{Si}}$ is shown in Fig. 7. The $\mathrm{SiO}_{2}$ sol is able to infiltrate deeper into the rattan powder through the pore structure at ambient temperature, thus coming into close contact with cell wall before the formation of $\mathrm{SiC}$. Conversely, Si remains mostly on the surface of the rattan powder, with little of Si coming into contact with the cell wall. With the continuous increase of temperature, the rattan powder was carbonized, infiltrated by liquid melt-Si spontaneously, and reacted with $\mathrm{Si}$ and $\mathrm{SiO}_{2}$ during the formation of $\mathrm{SiC}$. After the formation of $\mathrm{SiC}, \mathrm{R}-\mathrm{SiC}_{\mathrm{SiO} 2}$ possessed a porous structure and higher yield of $\mathrm{SiC}$, while most of $\mathrm{R}-\mathrm{SiC}_{\mathrm{Si}}$ was embedded by unreacted $\mathrm{Si}$, resulting in the rare appearance of pore structures and a lower yield of $\mathrm{SiC}$. Therefore, the $\mathrm{SiO}_{2}$ sol is more suitable for preparing high-yielding porous $\mathrm{R}-\mathrm{SiC}$ ceramic.

Table 2 Specific surface area of the rattan and rattan-base SiC (R$\mathrm{SiC})$ ceramics

\begin{tabular}{llll}
\hline & Sample & & \\
\cline { 2 - 4 } & Rattan powder & R-SiC $\mathrm{SiO}_{2}$ & R-SiC \\
\hline Specific surface area $\mathrm{m}^{2} / \mathrm{g}$ & 22.15 & 21.99 & 6.25 \\
\hline
\end{tabular}

$R-S i C$ rattan-base $\mathrm{SiC}$ 


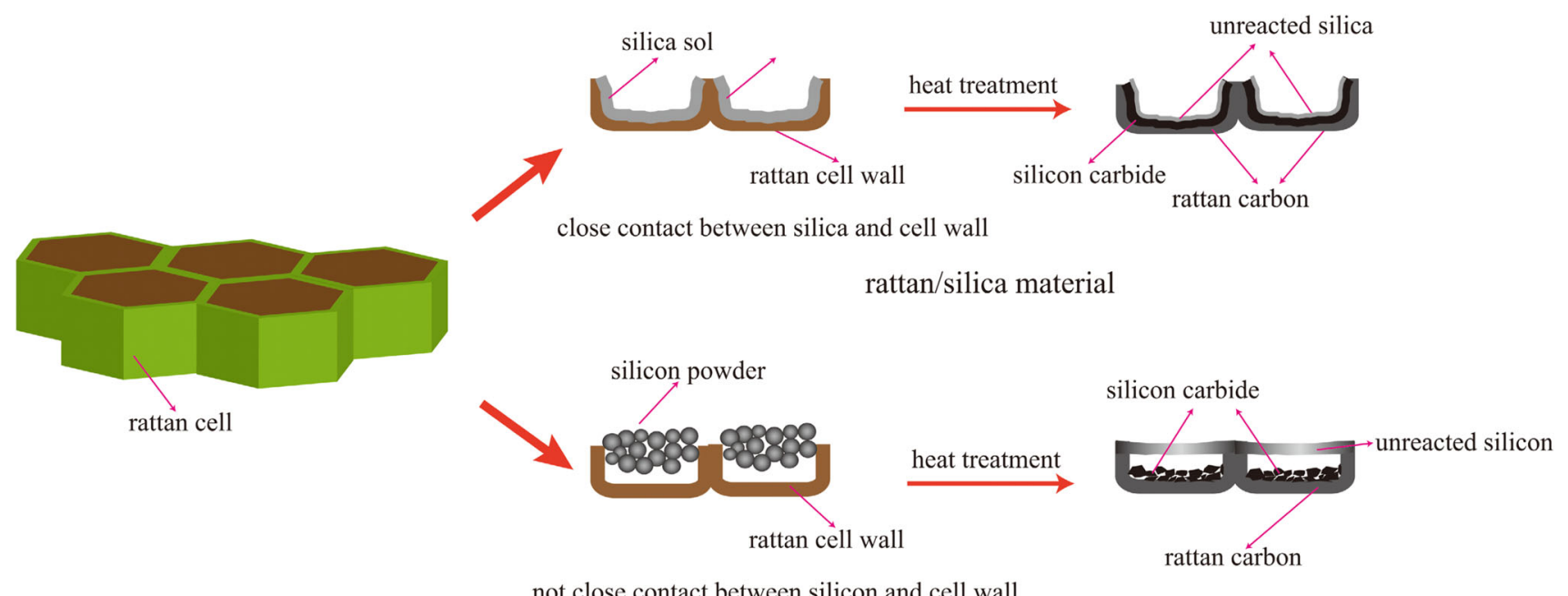

not close contact between silicon and cell wall

rattan/silicon material

Fig. 7 Schematic diagram illustrating the formation mechanism of $\mathrm{SiC}$ from $\mathrm{Si}$ powder and $\mathrm{SiO}_{2}$ sol

\section{Conclusions}

R-SiC ceramics, $\mathrm{R}-\mathrm{SiC}_{\mathrm{SiO} 2}$ and $\mathrm{R}-\mathrm{SiC}_{\mathrm{Si}}$, were successfully synthesized using $\mathrm{Si}$ powder and $\mathrm{SiO}_{2}$ sol, respectively. The $\mathrm{Si}$ source used had significant effects on compositions and morphologies of final $\mathrm{R}-\mathrm{SiC}_{\mathrm{SiO} 2}$ and $\mathrm{R}-\mathrm{SiC}_{\mathrm{Si}}$. The two $\mathrm{SiC}$ samples both consist of $\mathrm{SiC}, \mathrm{SiO}_{2}$, and unreacted $\mathrm{C}$, but $\mathrm{R}-\mathrm{SiC}_{\mathrm{Si}}$ contains a large amount of unreacted $\mathrm{Si} . \mathrm{SiO}_{2}$ sol has higher impregnation in the rattan powder than $\mathrm{Si}$, but neither of them can completely react with the rattan powder (carbon). Furthermore, the $\mathrm{SiO}_{2}$ sol has a higher yield of $\mathrm{SiC}$ than Si powder during the preparation of R-SiC ceramics. In addition to this, the porous morphology of rattan can remain intact in $\mathrm{R}-\mathrm{SiC}_{\mathrm{SiO} 2}$, while it is difficult to find in $\mathrm{R}-\mathrm{SiC} \mathrm{Si}_{\mathrm{Si}}$, resulting in a higher specific surface area of $\mathrm{R}-\mathrm{SiC}_{\mathrm{SiO} 2}$. The reasons for these differences are mainly due to $\mathrm{SiO}_{2}$ sol forming closer contact with the rattan cell wall than $\mathrm{Si}$ powder before the respective formation of $\mathrm{R}-\mathrm{SiC}_{\mathrm{SiO} 2}$ and $\mathrm{R}-\mathrm{SiC}_{\mathrm{Si}}$. The rod-like $\mathrm{SiC}$ whisker and tablet-like $\mathrm{SiC}$ particle can also be found in the pores of $\mathrm{R}-\mathrm{SiC}_{\mathrm{SiO} 2}$. The biomorphic porous $\mathrm{R}-\mathrm{SiC}_{\mathrm{SiO} 2}$ can be used as filters, catalyst supports, and porous burners at high temperature.

Acknowledgements The National Science-technology Support Plan Project (2012BAD54G0103) funded this research. The authors also wish to thank Prof. Yue Zhang from Beihang University, School of Materials Science and Engineering, for his help in guiding experimental work, and thank Mr. Oliver Frith from the International Network for Bamboo and Rattan (INBAR) for his revision of this manuscript.

\section{References}

1. Fan J, Chu PK (2014) Silicon carbide nanostructures: fabrication, structure, and properties. Springer, New York
2. Basu B, Balani K (2011) Advanced structural ceramics. Wiley, New York

3. Riley F (2009) Structural ceramics: fundamentals and case studies. Cambridge University, Cambridge

4. Saddow SE, Agarwal A (2004) Advances in silicon carbide processing and applications. Artech House, London

5. Miyafuji $\mathrm{H}$, Saka S (2001) $\mathrm{Na}_{2} \mathrm{O}-\mathrm{SiO}_{2}$ wood-inorganic composites prepared by the sol-gel process and their fire-resistant properties. J Wood Sci 47:483-489

6. Arellano-López AR, Martínez-Fernández J, Gonzalez P, Domínguez C, Fernández-Quero V, Singh M (2004) Biomorphic SiC: a new engineering ceramic material. Int J Appl Ceram Technol 1:56-67

7. Sieber H, Hoffmann C, Kaindl A, Greil P (2000) Biomorphic cellular ceramics. Adv Eng Mater 2:105-109

8. Chiew YL, Cheong KY (2011) A review on the synthesis of SiC from plant-based biomasses. Mater Sci Eng B 176:951-964

9. Maity A, Das H, Kalita D, Kayal N, Goswami T, Chakrabarti O (2014) Studies on formation and siliconization of carbon template of coir fibreboard precursor to SiC ceramics. J Eur Ceram Soc 34:3499-3511

10. Ishimaru $\mathrm{K}$, Hata $\mathrm{T}$, Bronsveld $\mathrm{P}$, Nishizawa $\mathrm{T}$, Imamura $\mathrm{Y}$ (2007) Characterization of sp2-and sp3-bonded carbon in wood charcoal. J Wood Sci 53:442-448

11. Zampieri A, Sieber H, Selvam T, Mabande GT, Schwieger W, Scheffler F, Scheffler M, Greil P (2005) Biomorphic cellular SiSiC/ zeolite ceramic composites: from rattan palm to bioinspired structured monoliths for catalysis and sorption. Adv Mater 17:344-349

12. Manocha SM, Patel H, Manocha LM (2013) Effect of steam activation on development of light weight biomorphic porous $\mathrm{SiC}$ from pine wood precursor. J Mater Eng Perform 22:396-404

13. Shin DW, Park SS, Choa YH, Niihara K (1999) Silicon/silicon carbide composites fabricated by infiltration of a silicon melt into charcoal. J Am Ceram Soc 82:3251-3253

14. Gordic M, Bucevac D, Ruzic J, Gavrilovic S, Hercigonja R, Stankovic M, Matovic B (2014) Biomimetic synthesis and properties of cellular SiC. Ceram Int 40:3699-3705

15. Egelja A, Gulicovski J, Devečerski A, Ninić M, RadosavljevićMihajlović A, Matović B (2008) Preparation of biomorphic SiC ceramics. Sci Sinter 40:141-145

16. Yan Z, Liu J, Zhang J, Ma T, Li Z (2011) Biomorphic silicon/ silicon carbide ceramics from birch powder. Ceram Int 37:725-730 
17. Vogli E, Sieber H, Greil P (2002) Biomorphic SiC-ceramic prepared by Si-vapor phaseinfiltration of wood. J Eur Ceram Soc 22:2663-2668

18. Vyshnyakova K, Yushin G, Pereselentseva L, Gogotsi Y (2006) Formation of porous $\mathrm{SiC}$ ceramics by pyrolysis of wood impregnated with silica. Int J Appl Ceram Technol 3:485-490

19. Locs J, Berzina-Cimdina L, Zhurinsh A, Loca D (2009) Optimized vacuum/pressure sol impregnation processing of wood for the synthesis of porous, biomorphic SiC ceramics. J Eur Ceram Soc 29:1513-1519

20. Bartuli C, Bemporad E, Tulliani JM, Tirillò J, Pulci G, Sebastiani M (2009) Mechanical properties of cellular ceramics obtained by gel casting: characterization and modeling. J Eur Ceram Soc 29:2979-2989

21. Rose M, Korenblit Y, Kockrick E, Borchardt L, Oschatz M, Kaskel S, Yushin G (2011) Hierarchical micro-and mesoporous carbide-derived carbon as a high-performance electrode material in supercapacitors. Small 7:1108-1117

22. Oschatz M, Kockrick E, Rose M, Borchardt L, Klein N, Senkovska I, Freudenberg T, Korenblit Y, Yushin G, Kaskel S (2010) A cubic ordered, mesoporous carbide-derived carbon for gas and energy storage applications. Carbon 48:3987-3992

23. Jiang ZH (2002) World bamboo and rattan. Liaoning Science \& Technique Press, Shenyang

24. Ebanyenle E, Oteng-Amoako AA (2005) Variation in some anatomical and physical properties of stems of five rattan palm species of Ghana. J Bamboo Rattan 4:125-142

25. Lin YJ, Lo XW (2011) Fabrication of SiC and SiC/aluminumsilicon composites from Rattan charcoal. Key Eng Mater 479:119-123

26. Rachchh NV, Ujeniya PS, Misra RK (2014) Mechanical characterisation of rattan fibre polyester composite. Procedia Mater Sci 6:1396-1404

27. Zampieri A, Kullmann S, Selvam T, Bauer J, Schwieger W, Sieber H, Fey T, Greil P (2006) Bioinspired rattan-derived SiSiC/ Zeolite monoliths: preparation and characterization. Micropor Mesopor Mat 90:162-174

28. Maisarah T, Ahmad Z, Roszalia A, Luqman MA (2015) Characterization of rattan waste for binderless particleboard (BPB) sampleion. Adv Mater Res 1115:317-320

29. Hameed BH, Ahmad AL, Latiff KNA (2007) Adsorption of basic dye (methylene blue) onto activated carbon prepared from rattan sawdust. Dyes Pigm 75:143-149
30. Vix-Guterl C, Ehrburger P (1997) Effect of the properties of a carbon substrate on its reaction with silica for silicon carbide formation. Carbon 35:1587-1592

31. Preiss H, Berger LM, Braun M (1995) Formation of black glasses and silicon carbide from binary carbonaceous/silica hydrogels. Carbon 33:1739-1746

32. Zhang J, Luo R (2011) An environmentally friendly route to prepare hierarchical carbon/carbon-SiC composites by carbothermal reduction. Carbon 49(1):339-342

33. DIN EN 725-9-2006 (2006) Advanced technical ceramicsmethods of test for ceramic powders-Part 9: determination of untapped bulk density. European Committee for Standardization, Berlin

34. Maity A, Kalita D, Kayal TK, Goswami T, Chakrabarti O, Maiti HS, Rao PG (2010) Synthesis of SiC ceramics from processed cellulosic bio-precursor. Ceram Int 36:323-331

35. Shin Y, Wang C, Samuels WD, Exarhos GJ (2007) Synthesis of SiC nanorods from bleached wood pulp. Mater Lett 61:2814-2817

36. Pan J, Pan J, Cheng X, Yan X, Lu Q, Zhang C (2014) Synthesis of hierarchical porous silicon oxycarbide ceramics from preceramic polymer and wood biomass composites. J Eur Ceram Soc $34: 249-256$

37. Xingzhong G, Lingie Z, Liqing Y, Hui Y, Lin Z (2010) Preparation of silicon carbide using bamboo charcoal as carbon source. Mater Lett 64:331-333

38. Sujirote K, Leangsuwan P (2003) Silicon carbide formation from pretreated rice husks. J Mater Sci 38:4739-4744

39. Segatelli MG, Pires ATN, Yoshida IVP (2014) Synthesis and structural characterization of carbon-rich $\mathrm{SiC}_{\mathrm{x}} \mathrm{O}_{\mathrm{y}}$ derived from a Ni-containing hybrid polymer. J Eur Ceram Soc 28:2247-2257

40. Mallick D, Chakrabarti OP, Maiti HS, Majumdar R (2007) Si/SiC ceramics from wood of Indian dicotyledonous mango tree. Ceram Int 33:1217-1222

41. Chakrabarti OP, Maiti HS, Majumdar R (2004) Si-SiC ceramics from plant precursor. J Mater Sci 39:4715-4717

42. Martĺnez-Fernández J, Valera-Feria FM, Singh M (2000) High temperature compressive mechanical behavior of biomorphic silicon carbide ceramics. Scr Mater 43:813-818

43. Cordelair J, Greil P (2000) Electrical conductivity measurements as a microprobe for structure transitions in polysiloxane derived Si-O-C ceramics. J Eur Ceram Soc 20:1947-1957 